\title{
De qual muçulmano estamos falando? Ancoragem e objetivação na representação do islamita pela revista Istoé
}

\section{André Melo Mendes}

Doutor; Universidade Federal de Minas Gerais, Belo Horizonte, MG, Brasil

andremelomendes@hotmail.com

\section{Raquel Dornelas}

Doutoranda;Universidade do Estado do Rio de Janeiro, Rio de Janeiro, RJ, Brasil

raqueldornelas@gmail.com

\section{Resumo}

O artigo busca entender como os muçulmanos foram representados pelas páginas da revista semanal Istoé, na ocasião dos atentados terroristas, na França, em janeiro e em novembro de 2015. Para isso, foram trabalhadas as noções de ancoragem e objetivação, entendendo-as como partes centrais da Teoria da Representação Social, de Serge Moscovici. Ao operacionalizar tais conceitos, utilizamos como ferramental uma análise imagética e textual, assim percebendo como o ato de representação demonstra outros aspectos da nossa própria sociedade e como a narrativa pesquisada problematiza a própria prática da imprensa. $O$ artigo conclui que as duas edições do periódico jornalístico representaram os muçulmanos sob três categorias: o bem-sucedido, a vítima e o terrorista - sendo esse último concretizado na figura do membro do Estado Islâmico.

\section{Palavras-chave}

Representação social. Ancoragem. Objetivação. Muçulmano. Terrorismo.

\section{Introdução}

Os árabes constituem-se como uma das civilizações mais antigas da história da humanidade. Eles influenciaram e ainda influenciam a culinária, a música, a religião e a ciência de grande parte de todo o mundo ocidental. A comunidade árabe é formada por um conjunto de povos localizados em pontos diversos, como na região desértica da Península 
Arábica, e que podem pertencer a diversas nacionalidades: turcos, libaneses, sírios e sauditas. Em um importante trecho de sua trajetória, eles estiveram inscritos em um contexto no qual o Oriente Médio era dividido entre o domínio persa e o domínio romano (LEWIS, 1996).

Ao contrário do que muitos pensam, o surgimento da civilização árabe e do islamismo não são fatos simultâneos. Por volta do século VII, a cidade de Meca (Arábia Ocidental) assistiu ao nascimento de um movimento religioso, liderado por Maomé: o Islã. Natural da referida cidade, o profeta era considerado um enviado de Deus (Alá) e encarregado de repassar a mensagem divina para os fiéis.

Aos seguidores do Islã, deu-se o nome de muçulmanos, termo derivado do vocábulo muslim - uma das possibilidades do verbo árabe aslama que significa "rendido". Após a morte de Maomé, líderes sucessores incumbiram-se da tarefa de dar prosseguimento à mensagem e à propagação do Islã. Um novo império surgiu: o Califado. 0 califa (khalifa) assumia a posição de líder político e, ao mesmo tempo, religioso.

Santos (2016) explica que o Islã tem três principais símbolos: o Corão, os cinco pilares (fé, oração, esmola, jejum e peregrinação) e a Shari'a - a lei que rege a conduta dos fiéis. 0 autor ainda esclarece que um dos motivos dos históricos conflitos envolvendo muçulmanos é a divisão existente dentro do Islã entre sunitas e xiitas - sendo esse último formado pela minoria dos seguidores de Maomé.

[...] o cisma se deu em virtude dos direitos de sucessão. Para os Sunitas, a sucessão deveria se dar pelo processo de liderança, ou seja, o conhecedor da Sunna (palavras e costumes/cotidiano do Profeta), para os Xiitas a sucessão seria por direito de descendência [...]. Os Xiitas são considerados infiéis pelos Sunitas por cultuarem santos (líderes religiosos) muçulmanos, visitando seus túmulos, permitirem a participação feminina em diversas situações junto aos homens. (SANTOS, 2016, p. 191-199).

Tal participação feminina causa inúmeras controvérsias e gera diferentes interpretações sobre o estilo de vida dos islamitas. Dependendo da região, da herança religiosa e dos costumes de cada povo, o tratamento dado às muçulmanas pode ser mais ou menos radical. Hourani (2006) explica que, apesar da ordem social do mundo muçulmano ser regida pela lógica masculina, o Corão apregoa a igualdade essencial entre homens e mulheres. Contudo, tal igualdade teria seus limites. A Shari'a, baseada no Corão, estabelece, por exemplo, que a mulher deve obediência ao homem, além de permitir que ele tenha mais de uma esposa. "Na medida em que uma família era rica, poderosa e respeitada, isolava suas 
mulheres numa parte especial da casa, o harém, e atrás de um véu quando elas se aventuravam a sair de casa para as ruas e lugares públicos." (HOURANI, 2006, p. 584).

A influência global do Islã é inegável. Segundo estatísticas de 2010, o islamismo é a segunda religião do mundo (23,2\% da população), perdendo apenas para o cristianismo (31,4\%). Em seguida, vem o hinduísmo (15\%), o budismo $(7,1 \%)$, as chamadas "religiões populares" (5,9\%), o judaísmo (0,2\%) e outras (0,8\%). Em todo o planeta, há ainda 16,4\% de pessoas que se declaram não seguidoras de uma doutrina (CENTRAL INTELLIGENCE AGENCY, 2017).

Apesar de sua inegável importância para o Ocidente, ao longo dos séculos, o islamismo tem sido, muitas vezes, ressignificado de maneira negativa, por imenso corpo de saber literário, erudito e científico. Isso levou intelectuais, como Edward Said, a concluir que o Oriente, como o Ocidente o conhece, é uma invenção que marca o leste da Europa como um povo exótico e inferior e que, portanto, deve ser civilizado (SAID, 2013). Essa imagem distorcida acentua-se a partir do século XVIII e tem sido agravada, especificamente, no presente século, devido ao atentado às torres gêmeas, em Nova York, em 11 de setembro de 2001 e ao crescimento de grupos terroristas como Al-Qaeda e Estado Islâmico (EI).

Apesar de, inicialmente, a Al-Qaeda ser considerada o "inimigo número um do mundo ocidental", nos últimos anos, o Estado Islâmico obteve uma capacidade de projeção impressionante, capaz de atingir, praticamente, qualquer grande capital europeia com suas ações que chocam o planeta pela sua ousadia e imprevisibilidade (WEBER, 2016, p. 100). Em grande parte do seu discurso público, o EI se apoia na escatologia islâmica em busca de legitimidade e mobilização. Segundo Weiss e Hassan (2016, p. 162), a frustração dos islamitas com as abordagens menos incisivas, para a criação de um estado islâmico, como a praticada pela Irmandade Mulçumana, por exemplo, os leva a pensar no EI como uma alternativa possível.

Desde início da década de 2010, as associações entre islamismo e terrorismo tornaram-se comuns, e os atentados provocados especificamente pelo Estado Islâmico, a partir de 2015, têm colaborado para essa distorção da imagem. É preciso ter atenção com essa associação visto que, como explicam Lasmar e Singh (2017, p. 51), tal afirmativa, além de não ser verdadeira, é irresponsável. Segundo os autores, existem inúmeros grupos terroristas não islâmicos, assim como “[...] são inúmeros os exemplos de grupos terroristas sem qualquer ligação com a questão religiosa." (LASMAR; SINGH, 2017, p. 51). 
Entre os atos dos radicais do EI, destacam-se aqui, dois ocorridos em Paris, capital da França: o ataque à redação do jornal satírico Charlie Hebdo, em janeiro de 2015 e os atentados em série espalhados por outros pontos da cidade, dez meses depois.

Em discussão anterior, já apresentamos os fatos mais detalhadamente e iniciamos uma análise sobre os dois acontecimentos, abordando as formas com as quais a revista Istoé acionou uma ação coletiva a partir das duas ocorrências (MENDES; DORNELAS, 2017). Agora, pretende-se entender como as mesmas páginas representaram a figura do muçulmano - envolvido ou não - nos ataques. Apreender como a revista revestiu de sentidos a imagem do seguidor do Islã poderá nos ajudar a entender melhor como a rede semântica reverberada pelos meios de comunicação tem figurado na própria tessitura social brasileira.

A metodologia ancora-se menos na busca por indicadores rígidos e mais em uma coleta de marcadores (inscrições textuais, imagéticas, icônicas) que possam dar pistas de como o relato da revista representou - intencionalmente ou não- ao longo da narrativa, o sentido atribuído ao muçulmano. No entanto, antes é preciso deixar mais claro o que podemos entender por representação social.

\section{Em que consistem as representações sociais?}

Como definir o termo "representação"? Conceitualmente, diferentes autores, de diferentes épocas e perspectivas, concentraram esforços para explorar o termo. Apenas como exemplos, podemos citar as discussões de Hall (1997), Jodelet $(1984,2003,2005)$, Goffman (2011) e Chartier $(1990,2002,2011)$ - bastante presentes em trabalhos do campo comunicacional.

Na produção científica em Comunicação, o termo tem sido adotado, especificamente, sob um viés que pode ser resumido pela perspectiva de Hall (1997). Para o autor, a representação pode ser entendida como um processo costurado pela linguagem para produzir sentidos acerca do mundo ao nosso redor. E é a própria linguagem que permite aos sujeitos sociais comungarem as representações e partilharem um mapa conceitual em comum.

Assim, é fácil encontrar produções acadêmicas que utilizam a noção de representação social para entender o estoque simbólico acionado pela ambiência midiática, a fim de dar 
sentido e estabelecer relações com grupos, acontecimentos e sujeitos, como um parâmetro para narrar os fatos ao nosso redor.

[...] o estudo das representações se apresenta como área de fundamental importância para o campo da comunicação, uma vez que as instâncias midiáticas, sejam elas o jornalismo, a publicidade, as narrativas ficcionais, estão constantemente oferecendo, reutilizando e se apropriando de representações imagéticas e textuais para construir seus discursos e promover a interação com seus públicos. (CORRÊA; SILVEIRA, 2014, p. 125).

Portanto, as representações nos ajudam a perceber os fatos e a transformar "o não familiar em familiar" - como explica Serge Moscovici. A propósito, o trabalho do autor romeno pode ser considerado um importante marco na chamada "teoria das representações sociais" e, não aleatoriamente, fornecerá o principal aporte conceitual desse estudo. De acordo com Moscovici (2012), as representações sociais nada mais são do que

Um sistema de valores, ideias e práticas, com uma dupla função: primeiro, estabelecer uma ordem que possibilitará as pessoas orientar-se em seu mundo material e social e controlá-lo; e, em segundo lugar, possibilitar que a comunicação seja possível entre os membros de uma comunidade, fornecendo-lhes um código para nomear e classificar, sem ambiguidade, os vários aspectos de seu mundo e da sua história individual e social. (MOSCOVICI, 2012, p. 35).

Percebemos, então, dois aspectos importantes na conceituação acima: a representação carrega um caráter referencial e, também, prescritivo. Como guias de leitura do mundo, elas orientam interpretações e comportamentos. Apesar disso, Moscovici (1978) não compreende a representação social como uma instância exterior aos sujeitos ou imposta à vida social. É, basicamente, nesse sentido, que o autor se inspira e, paradoxalmente, também, se diferencia do pensamento de Émile Durkheim - outro teórico que buscou compreender o conceito.

Antes de Serge Moscovici, Durkheim (1970) já se interessava pelo estabelecimento da definição de representação. A perspectiva do sociólogo acionava nomenclaturas diferentes para dois fenômenos distintos: representação coletiva e representação individual.

Durkheim (1970) traçou uma linha divisória entre as duas noções. Compreendendo o conceito sob uma visada sociológica, ele ateve-se a entender, principalmente, as nuances da representação coletiva. Moscovici (1978) admite ser devedor de Durkheim, mas não deixa de destacar a marca conceitual que os distingue, afirmando que o sociólogo interpretara a representação como um conceito, enquanto ele pretendia estudá-la enquanto um fenômeno. 
Durkheim, fiel à tradição aristotélica e kantiana, possui uma concepção bastante estática dessas representações [...]. Como consequência, representações, em sua teoria, são como o adensamento da neblina, ou, em outras palavras, elas agem como suportes para muitas palavras ou ideias. [...] nós a vemos [as representações] como estruturas dinâmicas, operando em um conjunto de relações e de comportamento que surgem e desaparecem, junto com as representações. (MOSCOVICI, 1978, p. 47).

Portanto, Moscovici (2007) pretendia investigar o caráter processual, a dinâmica de formação e funcionamento das representações sociais. Seu olhar lança luz para o momento da mudança, da novidade, da ruptura, quando surgem tensões ou desequilíbrios; ou seja, para a transformação que a representação provoca nos sujeitos e como esses mesmos sujeitos podem, também, transformá-las pela via da linguagem.

Farr (1995) ressalta a diferença entre os dois autores, afirmando que o termo representações coletivas (Durkheim) seria mais apropriado a

[...] um contexto de sociedades menos complexas, que eram de interesse [do sociólogo]. As sociedades modernas são caracterizadas pelo seu pluralismo e pela rapidez [...]. Há, nos dias de hoje, poucas representações que são verdadeiramente coletivas. (FARR, 1995, p. 45).

Assim, percebe-se um caráter acontecimental na perspectiva de Moscovici (2007). As representações são convenções, mas nem por isso deixam de ser mutáveis. Elas são apropriadas pelos indivíduos em inúmeras situações e configuram-se como ingrediente constitutivo das nossas interações comunicativas, originando interpretações que são elaboradas e ressignificadas pela própria dinâmica da sociedade.

Não é aleatório, portanto, o fato da teoria de Moscovici $(1978,2007)$ dar amplo espaço para a comunicação - razão pela qual seus estudos vão além do interesse de pesquisadores em psicologia social. Para o autor, a ação de representar só é possível por meio da linguagem - âmbito responsável por dar vida às representações, sendo, ao mesmo tempo, influenciada por estas.

\section{Os mecanismos de ancoragem e objetivação}

Ao olhar a representação sob uma perspectiva psicossocial, Serge Moscovici (2007) aciona os conceitos de ancoragem e objetivação. Segundo o autor, esses seriam dois processos distintos, mas interligados e responsáveis por gerar as representações do nosso mundo. Ainda, de acordo com Moscovici (2007), ambos os mecanismos sustentam-se no 
repertório em comum, em uma bagagem de sentidos socialmente compartilhada e socialmente construída, baseada em uma memória coletiva.

Especificamente, sobre a noção de ancoragem, outros teóricos também já a utilizaram como objeto de estudo: Barthes (1990), Doise, Clemence e Lorenzi-Cioldi (1992), Ordaz e Vala (1997). Certas perspectivas encontram interseções com a própria formulação de Moscovici (2007) e outras seguiram caminhos distintos. Na visão do autor romeno - a que será adotada aqui - a ancoragem diz respeito a um mecanismo cujo objetivo é diminuir a estranheza dos fenômenos com os quais nos deparamos em nossa vida social. Ancorar significa reduzir o caráter de incompreensibilidade e tornar o fato novo o mais familiar possível - diminuindo sua potência de ameaça. Formando opiniões, a ancoragem também nos permite avaliar o elemento não familiar e prescrever condutas. Ancorar é, portanto, orientar comportamentos, ou nas palavras do próprio Moscovici (2007), estipular “[...] o que é, ou não, permitido." (MOSCOVICI, 2007, p. 62).

$\mathrm{Na}$ ancoragem, classificamos o elemento estranho, comparando-o a categorias e modelos que nos soam mais familiar. Moscovici (2007) explica que, ao realizarmos tal aproximação, o fato/sujeito/fenômeno desconhecido herda as características da categoria para a qual o deslocamos. 0 autor ainda alerta que o componente perturbador pode até mesmo ser reajustado para que se enquadre na categoria na qual o inserimos.

Se a classificação, assim obtida, é geralmente aceita, então qualquer opinião que se relacione com a categoria irá se relacionar também com o objeto ou com a ideia. [...] Mesmo quando estamos conscientes de alguma discrepância, da relatividade de nossa avaliação, nós nos fixamos nessa transferência, mesmo que seja apenas para podermos garantir um mínimo de coerência entre o desconhecido e o conhecido. (MOSCOVICI, 2007, p. 61).

Tal classificação exige, na maioria das vezes, o acionamento de um "protótipo" - uma figura representativa da categoria em questão. Quando pensamos na categoria social "telejornalismo", por exemplo, o protótipo que vem à mente é de um programa com tom sóbrio, em que apresentadores se vestirão de maneira formal, geralmente, sentados em uma bancada, e relatarão, com o acionamento das reportagens em vídeo, os principais fatos do dia.

A classificação ou categorização, também implica no ato de nomear o fato, quando “[...] nós o libertamos de um anonimato perturbador, para dotá-lo de uma genealogia e para 
incluí-lo em um complexo de palavras específicas, para localizá-lo, de fato, na matriz de identidade da nossa cultura." (MOSCOVICI, 2007, p. 66, grifo do autor).

Ao nomear, segundo Moscovici (2007), formamos opiniões e especulamos sobre as intenções do elemento estranho. Então, se afirmamos que houve um golpe e não uma revolução, todos os predicados associados à primeira palavra são acionados. A matriz que identifica o termo expõe uma rede de sentidos socialmente compartilhada: golpe remete à desonestidade, abuso de força e/ou poder, deslegitimidade etc.

O segundo componente da representação social, na perspectiva de Moscovici (2007), é a objetivação. Tal mecanismo tem como função materializar o sentido e permitir que desloquemos o componente simbólico para um âmbito mais palpável. Objetivamos fatos outrora estranhos, "[...] reproduzindo-o[s] entre as coisas que nós podemos ver e tocar e, consequentemente, controlar." (MOSCOVICI, 2007, p. 61, grifo nosso). Moscovici (2007) explica que a objetivação é um processo mais atuante que a ancoragem, sendo responsável por tornar as representações mais reais - ou realizadas.

Assim, depois de nos depararmos com o desconhecido, nos vemos impelidos a ligá-lo a um elemento concreto e a dar-lhe uma existência própria. Moscovici (2007) dá como exemplo o fato de que, comumente, associamos a ideia de Deus (abstrata) à figura de um pai (concreto). Trata-se de um esforço que consegue revestir um conceito de seu equivalente icônico, imagético, conhecido, e como o qual conseguimos lidar mais facilmente.

A imagem do conceito deixa de ser um signo e torna-se réplica da realidade [...]. A noção, pois, ou a entidade da qual ela proveio, perde seu caráter abstrato, arbitrário e adquire uma existência quase física, independente. [...] as imagens se tornam elementos da realidade, em vez de elementos do pensamento. (MOSCOVICI, 2007, p. 74).

A ideia de objetivação em Moscovici (2007) destaca, então, o caráter autônomo do fenômeno objetivado. Ao revestir de existência um fato/fenômeno/sujeito e ao dar-lhe certa independência, ele passa a ser aceito como componente da nossa vida em comum, em um movimento de naturalização.

Então, tanto o processo de objetivação quanto o de ancoragem nada mais são do que a soma de elaborações socialmente compartilhadas e que confirmam suas existências na própria vivência social, em um movimento dinâmico e, também, mutável na história e no tempo.

Ancoragem e objetivação são, pois, maneiras de lidar com a memória. A primeira mantém a memória em movimento e a memória é dirigida para dentro, está sempre colocando e tirando objetos, pessoas e acontecimentos 
que ela classifica de acordo com um tipo e os rotula com um nome. A segunda, sendo mais ou menos direcionada para fora (para os outros), tira daí conceitos e imagens para juntá-los e reproduzi-los no mundo exterior para fazer as coisas conhecidas a partir do que já é conhecido. (MOSCOVICI, 2007, p. 78).

Portanto, cabe, novamente, sublinhar aqui que a teoria de Moscovici $(1978,2007)$, de forma alguma, encara as representações como algo estático ou a priori da vida social. Elas não se impõem sobre os indivíduos de maneira determinista - já que são esses mesmos indivíduos que as criam e as transformam. Por isso mesmo, apesar de seu caráter convencional e objetivado, elas não estão imunes a mudanças e a adequações.

Nesse sentido, partiremos, pois, à análise das representações sociais do sujeito "muçulmano" acionadas pela revista Istoé, na ocasião dos dois atentados ocorridos em Paris, no ano de 2015. Tentaremos perceber a dinâmica, o acionamento de categorias e sentidos pela via das narrativas verbais e não verbais, buscando compreender, também, possíveis elementos de prescrição. Se uma das formas de concretização ou de alcance das representações é por meio da materialidade discursiva, tentaremos entender como as inscrições textuais e imagéticas utilizadas pela Istoé ajudam a construir uma definição do que seja o seguidor do Islã.

\section{0 que significa ser muçulmano?}

Ao nos perguntamos que mecanismos discursivos foram acionados pela Istoé em sua narrativa sobre os ataques envolvendo muçulmanos, podemos indagar como tais representações podem contribuir para a formação de um imaginário de sentidos relativos a esse grupo.

Em 7 de janeiro de 2015, a sede do jornal Charlie Hebdo foi invadida por dois homens armados em Paris. Aos gritos de "Allahuakbar" (Deus é grande), eles fuzilaram 12 pessoas. 0 motivo desse massacre estava diretamente relacionado às sátiras que esse veículo havia publicado sobre o profeta Maomé e o islamismo. As principais revistas brasileiras deram destaque ao acontecimento e com a Istoé não foi diferente. 
Figura 1 - Panorarama geral da edição sobre o ataque ao Charlie Ebdo
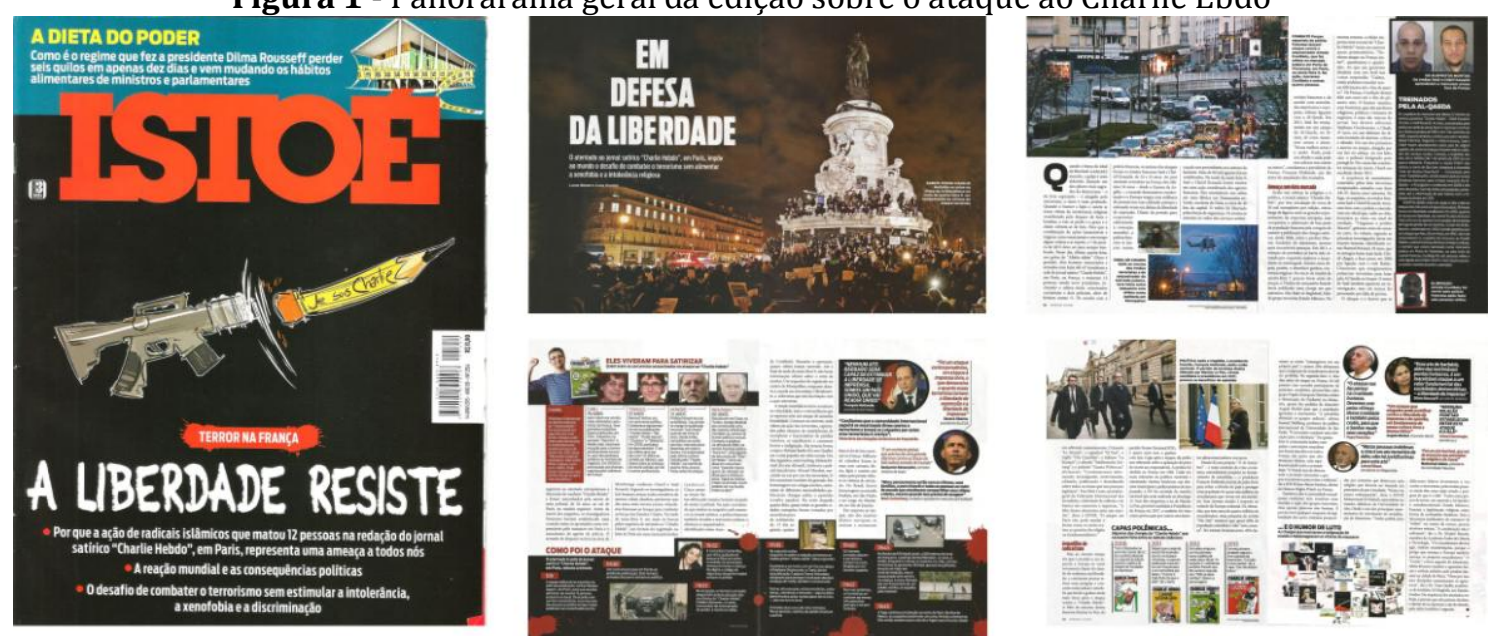

Fonte: Adaptação a partir da revista Istoé (2015a).

Na edição de 14 de janeiro (ISTOÉ, 2015a), a primeira imagem envolvendo muçulmanos está localizada em um box (Fig. 2). Na parte superior, percebem-se dois rostos situados sobre uma coluna preta e, no rodapé, encontra-se a imagem do terceiro terrorista. São imagens de arquivo, provavelmente fotos $3 \times 4$ de algum documento oficial. Todos apresentam um biótipo árabe, mas poderiam passar por brasileiros sem muita dificuldade dada à nossa miscigenação. Contudo, nesta ocasião, os nomes são marcadores que os definem claramente como membros mais prováveis do mundo oriental: Said e Chérif Kouach.

Figura 2 - Página contendo o box que apresenta os terroristas

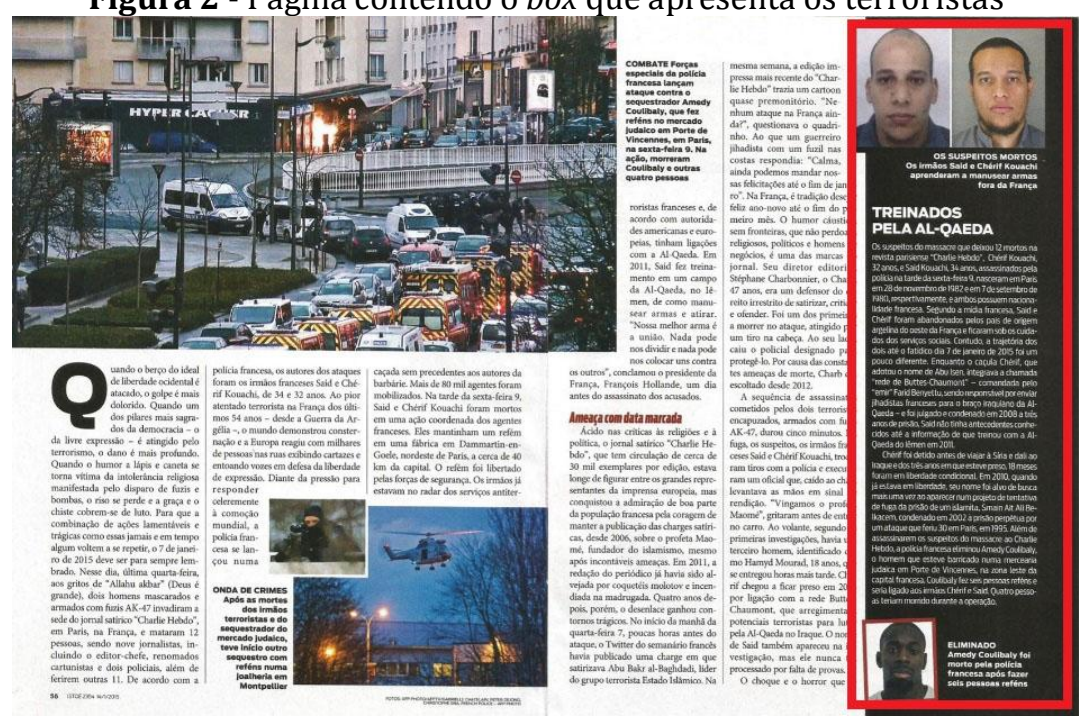

Fonte: Istoé (2015a, p. 56-57). 
O título do box é "Treinados pela Al-Qaeda". 0 texto vincula os suspeitos dos ataques ao grupo conhecido pela ação em 11 de setembro de 2001. Por meio do processo de ancoragem, ao serem categorizados como associados à Al-Qaeda, os suspeitos de Paris passam a herdar, no imaginário social, as características e os afetos que grande parte do mundo ocidental nutre pela rede à qual pertencia Osama Bin Laden.

Além do caráter referencial, percebe-se aqui outro importante aspecto da representação: o prescritivo. Após os atentados às Torres Gêmeas, a Al-Qaeda tornou-se "inimigo número um" dos Estados Unidos, ao mesmo tempo em que foi categorizada por grande parte da população do mundo ocidental, como um perigo global, um mal a ser combatido. Esse discurso justificou a intervenção norte-americana em regiões do Oriente durante vários anos. Ao resgatar a Al-Qaeda na memória coletiva, o mosaico de sentidos da rede de Bin Laden se projeta, também, sobre os terroristas que atacaram o Charlie Ebdo na França.

Figura 3 - Infográfico com a linha do tempo do ataque ao Charlie Ebdo
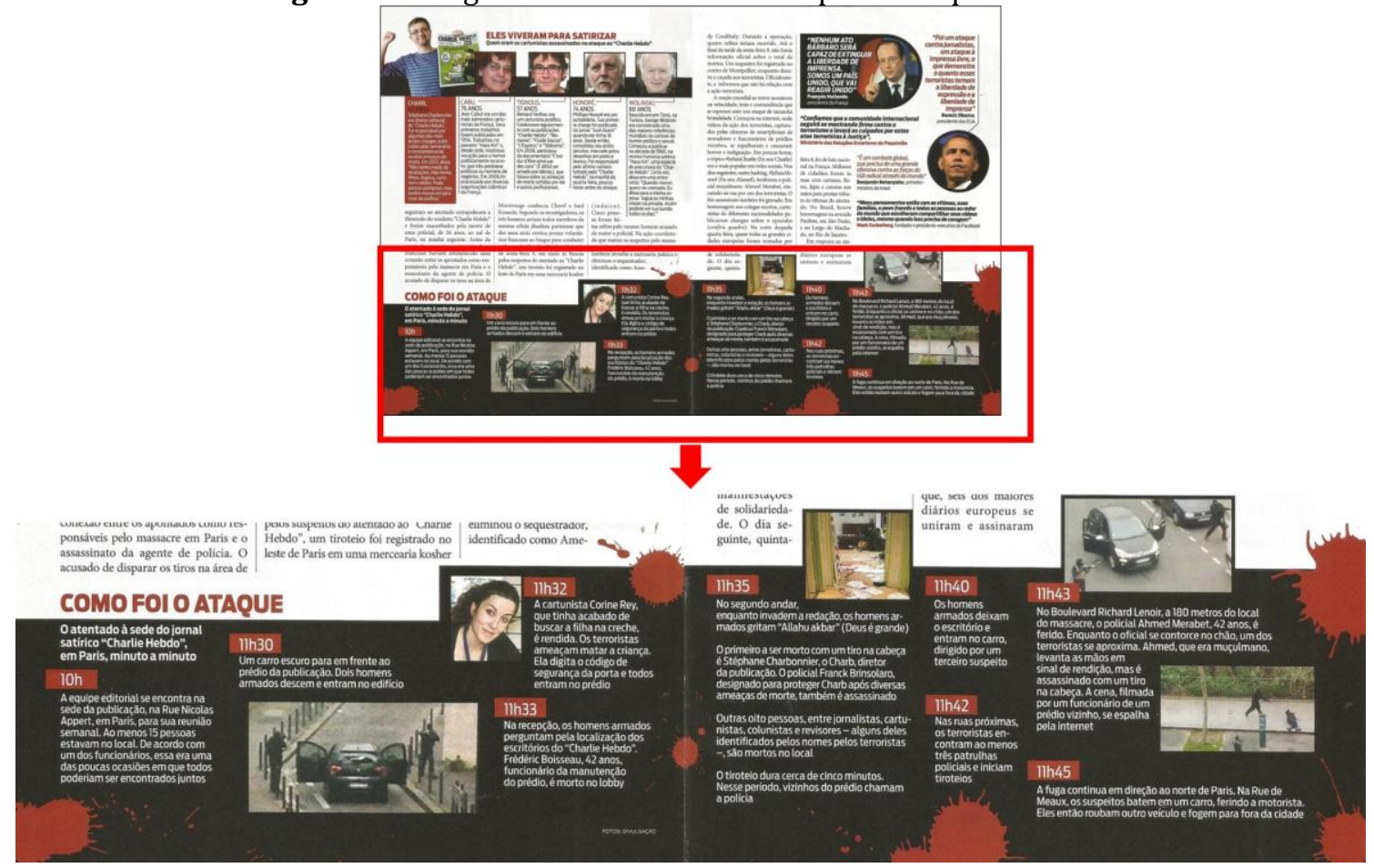

Fonte: Adaptação a partir de conteúdo da revista Istoé (2015a, p. 58-59).

O segundo momento em que muçulmanos são figurados na matéria é na página dupla seguinte (Fig. 3). A representação do ataque seguido de muitas mortes conta com o reforço dos sinalizadores visuais. Há um infográfico cujo fundo é escuro e apresenta círculos 
vermelhos que se assemelham a gotas de sangue. Aqui, percebemos outro movimento de ancoragem: imputa-se ao fato uma matriz de identidade típica dos sentidos que circundam a representação da morte. 0 vermelho, cor do sangue, está ligado aos assassinatos e contrasta com a cor escura, do fundo e da roupa dos terroristas, que remete ao luto.

Como já vimos, a categorização constitui-se como um traço central do processo de ancoragem. Em todas as representações visuais do infográfico (Fig. 3), os muçulmanos são apresentados como pessoas de identidade desconhecida, que portam rifles automáticos e usam máscaras, ou seja, são sujeitos misteriosos (rostos tampados) em ação: pulando o muro, atirando e, portanto, remetendo à periculosidade.

Tal semântica é reforçada na última imagem do infográfico: um dos homens mascarados atira em um policial ferido, deitado no chão. A cena, que já havia sido reproduzida na capa de vários jornais do mundo, para anunciar o atentado, mobiliza uma rede de sentidos que aproxima a ideia de covardia à categoria "muçulmano terrorista".

Além disso, o acionamento do recurso de uma linha do tempo, a fim de explicitar a narrativa, ilustra outro elemento da Teoria da Representação Social, de Moscovici (1978, 2007): ancorar-se, na perspectiva do autor, significa reduzir o caráter de incompreensibilidade e tornar o fato novo o mais familiar possível; a recorrência a um fio temporal pode contribuir para o entendimento do leitor. A utilização de fotografias e acontecimentos que se encadeiam como em um filme de ação imputa uma narrativa inteligível e, ao mesmo tempo, mais atrativa.

Já na página dupla seguinte (Fig. 4), em meio à imagem de diversos líderes ocidentais, inclusive da então presidente Dilma Rousseff, aparece a fotografia de Ashraf Ghani, presidente do Afeganistão.

Figura 4 - Lideranças mundiais opinam sobre o atentado ao Charlie Ebdo

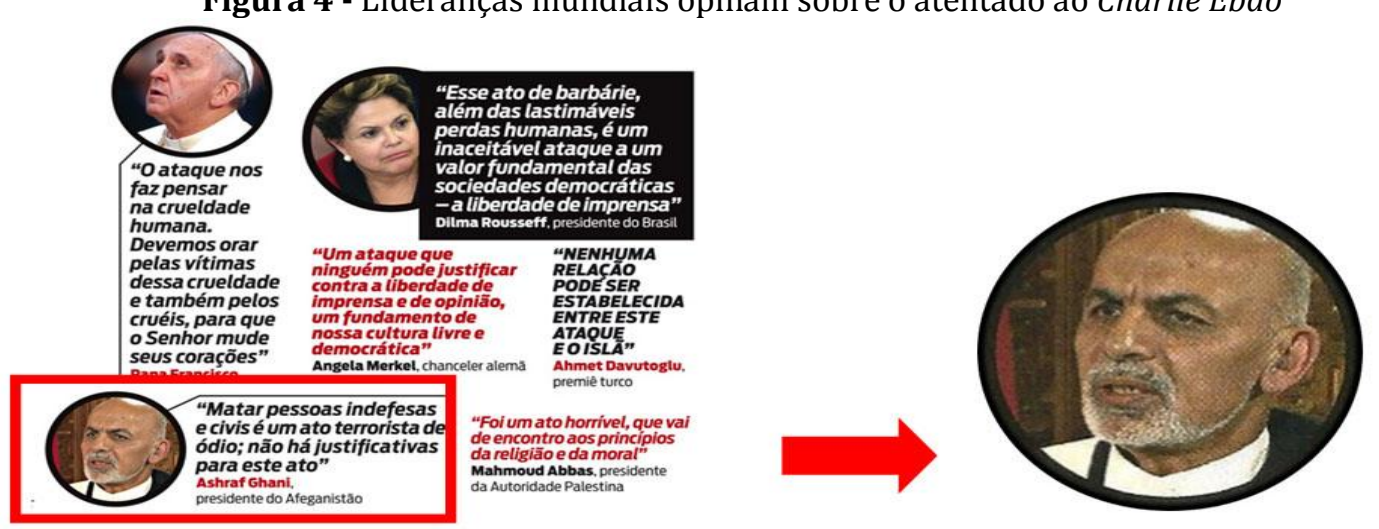

Fonte: Adaptação a partir de imagens da revista Istoé (2015a, p. 60-61). 
Na matéria da edição de 14 de janeiro, essa foi a única imagem encontrada de um muçulmano representado de maneira dissociada às mortes ocorridas. Asharf tem o aspecto de um homem de meia idade, calvo, com a tez morena, a barba quase toda branca, bem feita, e a expressão é séria. Sua figura sugere respeito, cuidado e confiabilidade. 0 fato de ele estar posicionado abaixo do Papa Francisco e da presidente Dilma Rousseff pode apontar para uma hierarquia e diminuir sua importância no cenário geral dos líderes internacionais relevantes apresentados.

É interessante reparar que há uma oposição sutil entre o Papa, líder dos católicos, e Ashar, líder muçulmano, que pode ser notada além da diagramação na página (o Papa, no topo, e Ashar, embaixo). A diferença também é perceptível nas falas associadas aos dois. Enquanto o Papa tem um posicionamento que abrange preocupação tanto com os culpados quanto com as vítimas, exortando-as ao perdão, a frase associada a Ashar sugere uma postura mais radical, que não prevê a possibilidade de perdão para os culpados.

Observa-se, nessa construção, uma representação parcial da dualidade Ocidente/Oriente, cristãos/não-cristãos. Mesmo que de forma bastante sutil, a hierarquia presente na ótica dos ocidentais manifesta-se na escolha e no posicionamento das fotografias na página, na fala e na expressão dos dois líderes religiosos. Se tal infografia fosse veiculada em um país predominantemente muçulmano, é provável que houvesse uma representação distinta da que foi veiculada pela revista brasileira.

\section{Paris novamente}

O mundo ocidental ainda não havia se recuperado do choque das mortes ocorridas no início do ano quando, em novembro de 2015, sete integrantes do grupo terrorista Estado Islâmico promoveram uma segunda ação - mais planejada - que atingiu diversos pontos da capital francesa. Nesse ataque, foram utilizados explosivos e armas de fogo, matando 129 pessoas em um restaurante, em três bares, em uma pizzaria e na casa de shows Bataclan (MENDES; DORNELAS, 2017). 
Figura 5 - Panorama geral da edição especial sobre os ataques em série
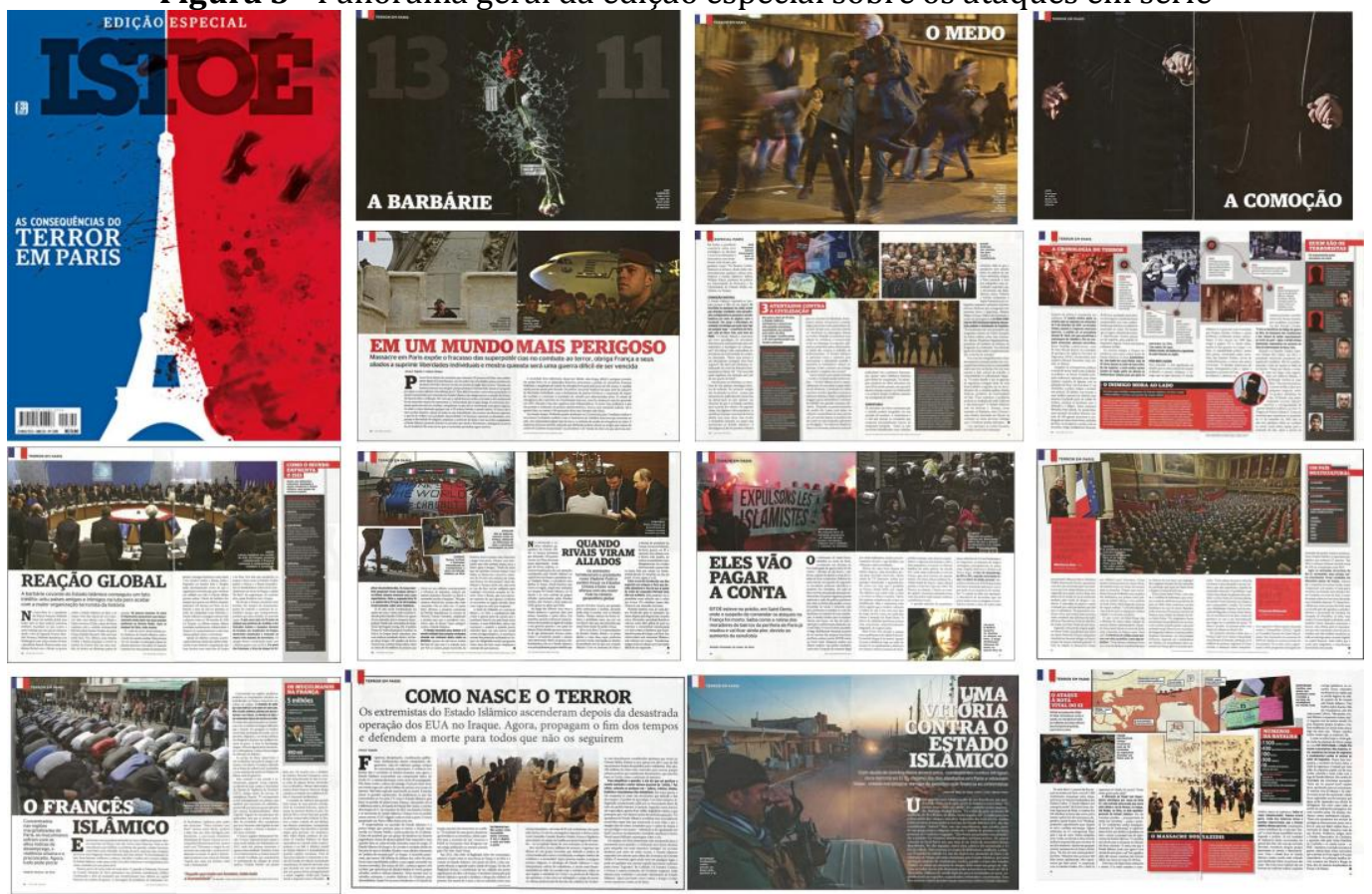

Fonte: Adaptação a partir da revista Istoé (2015b).

Diferentemente da cobertura dos atentados de janeiro, dessa vez a Istoé (2015b) optou por uma edição especial que incluiu uma abertura com três páginas duplas, localizadas antes da matéria principal propriamente dita. Em tal espaço, foram mostradas, exclusivamente, pessoas em situação de pânico e solidariedade. Há pouco texto e nítida prioridade à informação e expressividade imagética. A figura de um muçulmano só vai aparecer na nona página da reportagem (Fig. 6) - logo após a referida abertura.

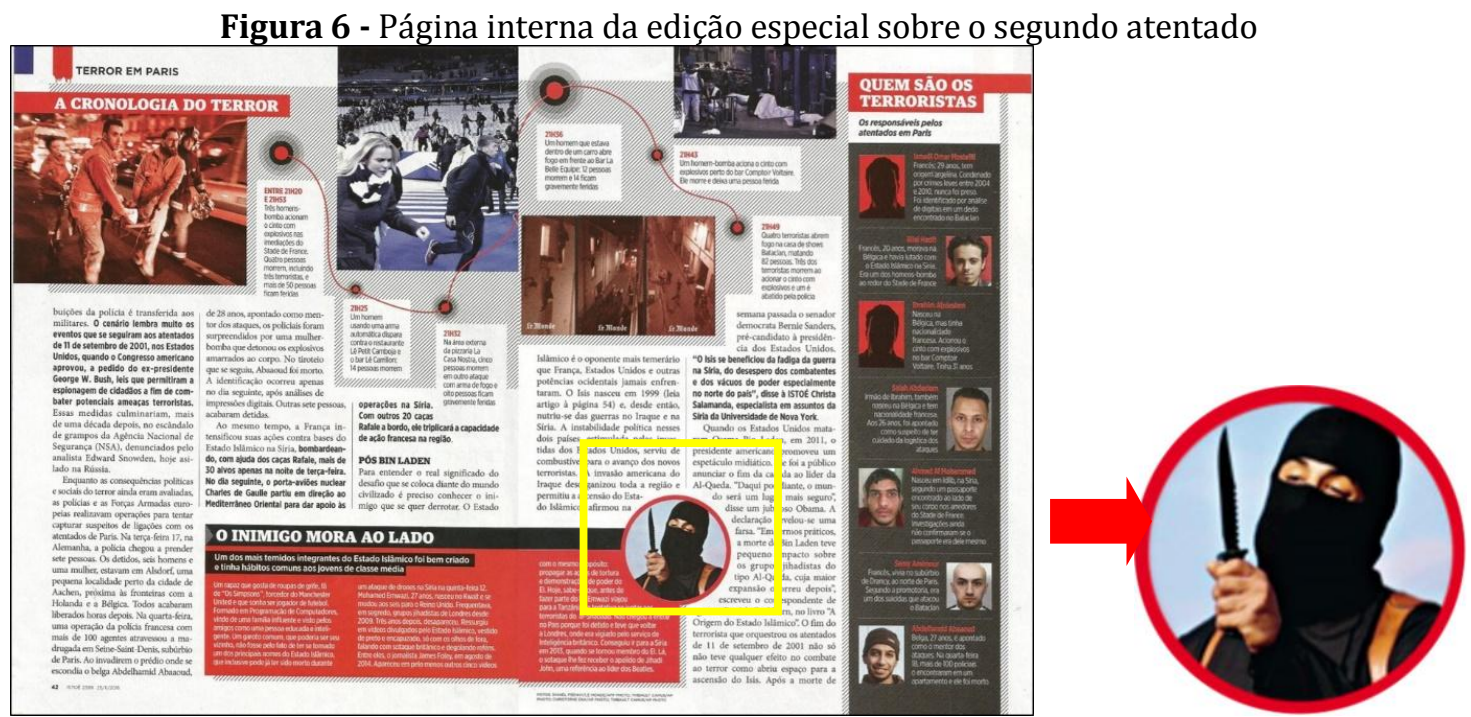

Fonte: Adaptação a partir de conteúdo da revista Istoé (2015b, p. 42-43). 
Na imagem acima, podemos perceber uma coluna cinza escura vertical, na qual são mostradas fotografias $3 \times 4$ dos terroristas e uma faixa horizontal vermelha em que há um homem com máscara, segurando uma faca preta. A imagem do mascarado deriva de uma famosa fotografia veiculada nos meios de comunicação e nas redes sociais, a partir de janeiro de 2015, na qual um membro do EI faz ameaças à vida de dois cidadãos japoneses 1 . Esse militante, conhecido como "Jihadi John", ganhou a cena pública ao participar de uma série de vídeos nos quais decapitava reféns capturados pelo EI, entre eles, jornalistas ${ }^{2}$.

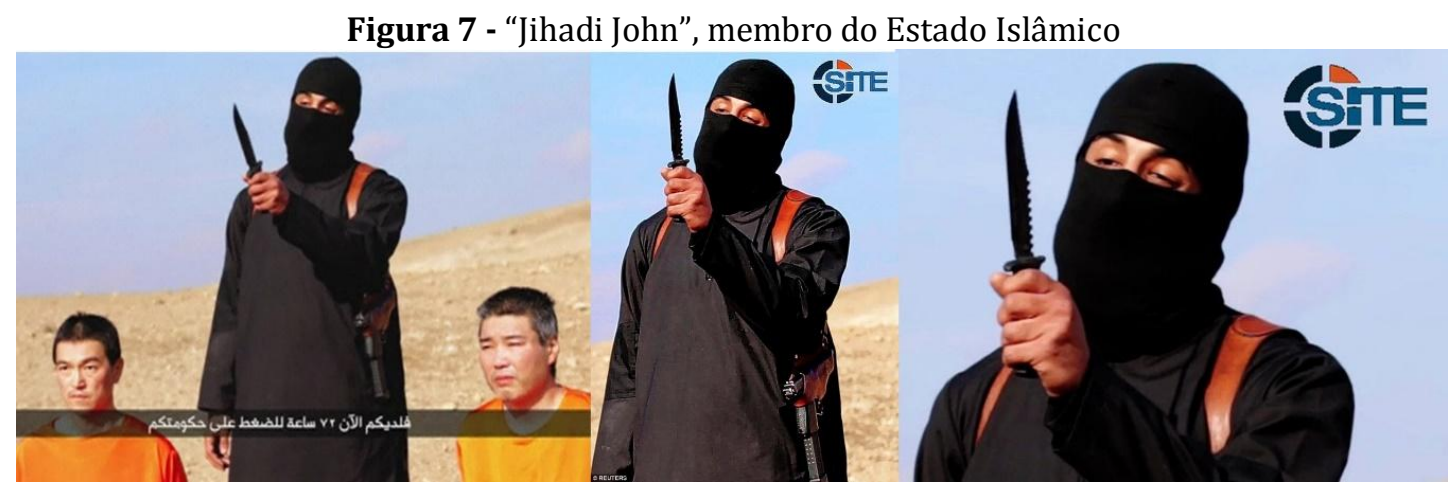

Fonte: Elaboração pelo autor a partir de vídeo divulgado pelo site G1 (2015).

O uso da imagem sugere aspectos bastante negativos para a caracterização do muçulmano, uma vez que o define não apenas como "inimigo", mas também como "bárbaro". Tais afirmações visuais e textuais sugerem que o novo tipo de terrorista é mais perigoso, pois não seria um inimigo "previsível" e facilmente identificável, mas um integrante da própria sociedade europeia. Tal sujeito, assim como vários outros terroristas de hoje, nasceu/morou na Europa e viveu como europeu por um bom tempo. Daí, a ideia de que ele poderia ser qualquer um da comunidade, inclusive um vizinho - fato explorado pelo título do box: "O inimigo mora ao lado" (Fig. 6).

Nesse sentido, ao trazer a fotografia de um membro reconhecível do EI, a representação do terrorista é conformada pela ancoragem entre a imagem escolhida e a imagem conhecida que se espalhou pelas redes sociais. 0 sujeito apresentado seria, assim, o protótipo do terrorista do EI: uma figura intolerante e cruel, que pode ser um vizinho, mas capaz de protagonizar vídeos chocantes de decapitação de reféns.

\footnotetext{
${ }^{1}$ No vídeo, os terroristas exigiam que o governo japonês pagasse US\$200 milhões no prazo de 72 horas como resgate das vítimas (AGÊNCIA BRASIL, 2015).

2 "Jihadi John" nasceu no Kuwait em 1988 e apareceu ainda nos vídeos que mostravam as execuções dos jornalistas americanos Steven Sotloff e James Foley, e do repórter japonês Kenji Goto (G1, 2015).
} 
Ainda na mesma página, podemos ver, na coluna cinza escuro, os rostos dos envolvidos no ataque terrorista. Tal como na reportagem veiculada em janeiro, as faces dos responsáveis pelos atentados de Paris são apresentadas ao leitor em uma única coluna.

De um modo geral, são homens jovens, com leves traços árabes. No entanto, seus nomes não deixam dúvidas sobre sua ascendência. Todos eles eram nascidos na Europa (França ou Bélgica), à exceção de Ahmad Al Mohammed, natural da Síria.

A última foto da coluna é de Abdelhamid Abaasoud, o jovem belga considerado mentor dos ataques. Ao contrário dos outros muçulmanos da coluna, sua expressão é alegre, descontraída: ele sorri para a câmera. Mais adiante, na matéria "Eles vão pagar a conta" (Fig. 8), a imagem de Abdelhamid aparece novamente e, mais uma vez, é apresentado como um rapaz sorridente.

Figura 8 - Imagens de Abdelhamida Abaasoud veiculadas na revista Istoé

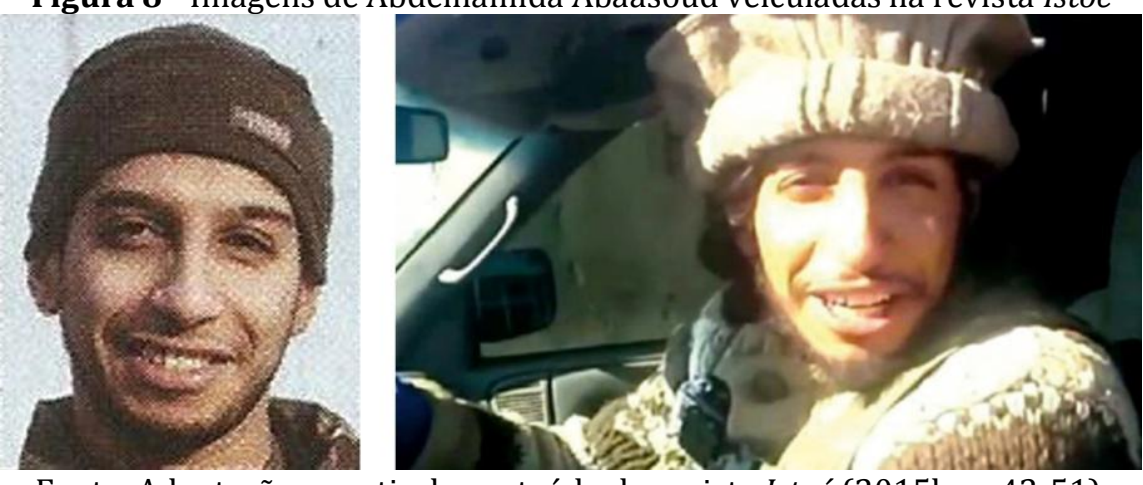

Fonte: Adaptação a partir de conteúdo da revista Istoé (2015b, p. 43-51).

A escolha dessas duas imagens para representar o suspeito de articular o atentado terrorista de novembro acaba reforçando a ideia de que se trata de um jovem aparentemente inofensivo - a propósito, ele é um cidadão belga. Tal escolha pode ter mais uma vez favorecido a fixação, no imaginário ocidental, da ideia de que os terroristas podem ser pessoas "comuns", pertencerem à comunidade europeia, corroborando com a ameaça contida no título "O inimigo mora ao lado" (Fig. 6).

Nas páginas seguintes (Fig. 9 e 11) da cobertura especial, seguem duas matérias: "Eles vão pagar a conta" e "O francês islâmico". Ambas apresentam o argumento de que a marginalização do mulçumano e sua vida na Europa deverão piorar após os ataques terroristas em série. A mensagem que pode ser deduzida é: o terrorismo é ruim também para os próprios islamitas, mesmo aqueles que não têm ligação nenhuma com os atos. Em "Eles vão pagar a conta" (Fig. 9), fica evidente o medo do crescimento da xenofobia e do endurecimento da polícia contra os seguidores do Islã. Já em “O francês islâmico” (Fig. 11), 
discutem-se as falhas do estado francês ao não promover a integração entre os diversos imigrantes ou descendentes desses imigrantes.

Figura 9 - Matéria tenta prever as consequências dos ataques para os muçulmanos na Europa

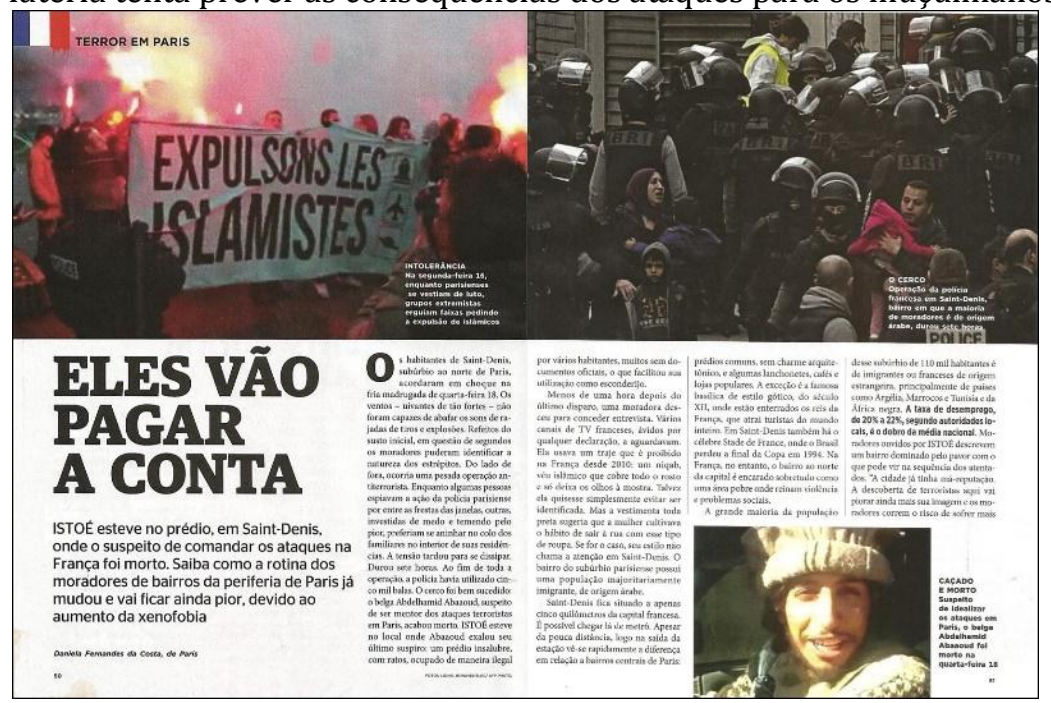

Fonte: Istoé (2015b, p. 50-51).

$\mathrm{Na}$ primeira matéria, o conjunto de imagens/texto pretende confirmar o possível acirramento da xenofobia, apresentando uma imagem em que manifestantes seguram um cartaz pedindo a expulsão dos islamitas. Em outra fotografia, localizada à direita da página (Fig. 10), fica evidente a ação rigorosa da polícia em uma comunidade na qual a maioria é de descendência árabe.

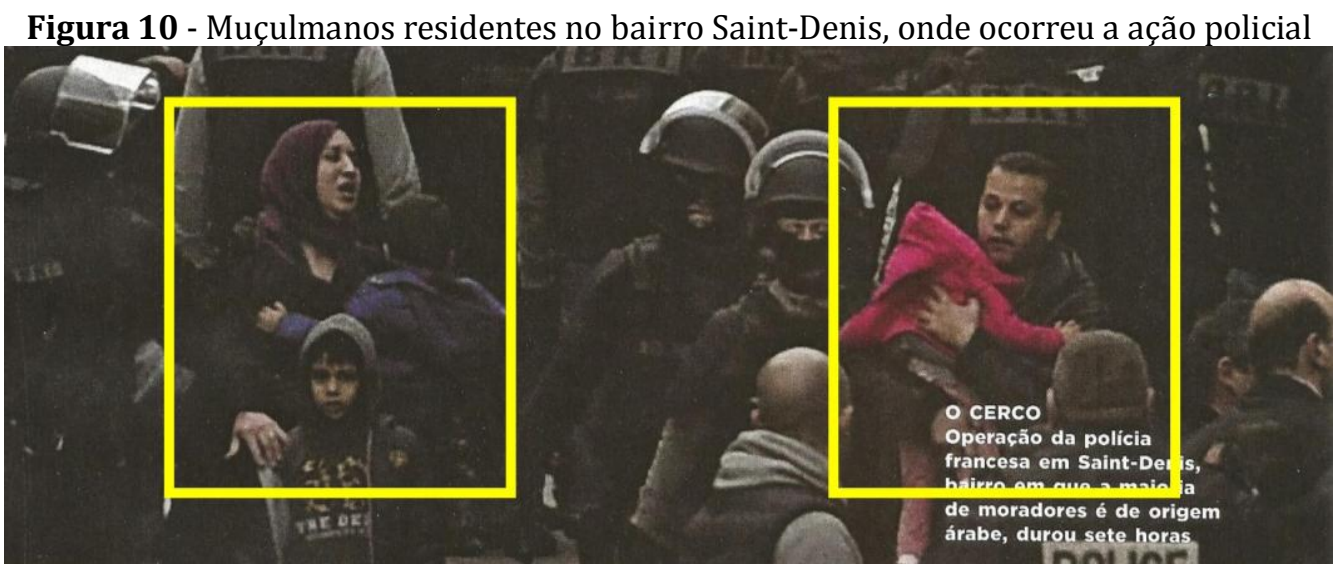

Fonte: Adaptação a partir de conteúdo da revista Istoé (2015b, p. 50-51).

Nessa cena (Fig. 10), a mulher com lenço na cabeça, segurando um menino no colo e junto à outra criança é caracterizada como uma mãe muçulmana, vítima da ação da polícia. 
Ao apresentar uma figura que se enquadra na categoria "mãe", a revista aciona uma rede de sentidos ligados ao instinto de proteção e amor - no caso específico da fotografia. 0 homem com os meninos está próximo; pode ser lido como o "companheiro" e, assim, eles fariam parte de uma família mulçumana. A tensão da cena representa o protótipo das "vítimas do terror": pessoas e lares permeados pelo pavor e que são obrigados a mudar configurações de vida em função da ameaça terrorista.

Se a mulher com as duas crianças for vinculada ao homem (também com crianças), temos sutilmente sugerida outra característica dos povos muçulmanos que preocupam algumas correntes: a alta taxa de natalidade desses grupos. Tal característica alimentaria a fantasia de que um dia os imigrantes muçulmanos vão "dominar" a Europa, graças a uma taxa de crescimento demográfico bem superior a dos ocidentais ${ }^{3}$.

A matéria seguinte (Fig. 11) apresenta outros mulçumanos europeus - dessa vez, desconectando a imagem do seguidor do Islã ao terror. Aqui, sem dúvida, é o momento das duas reportagens em que a figura do muçulmano aparece de forma mais positiva na Istoé.

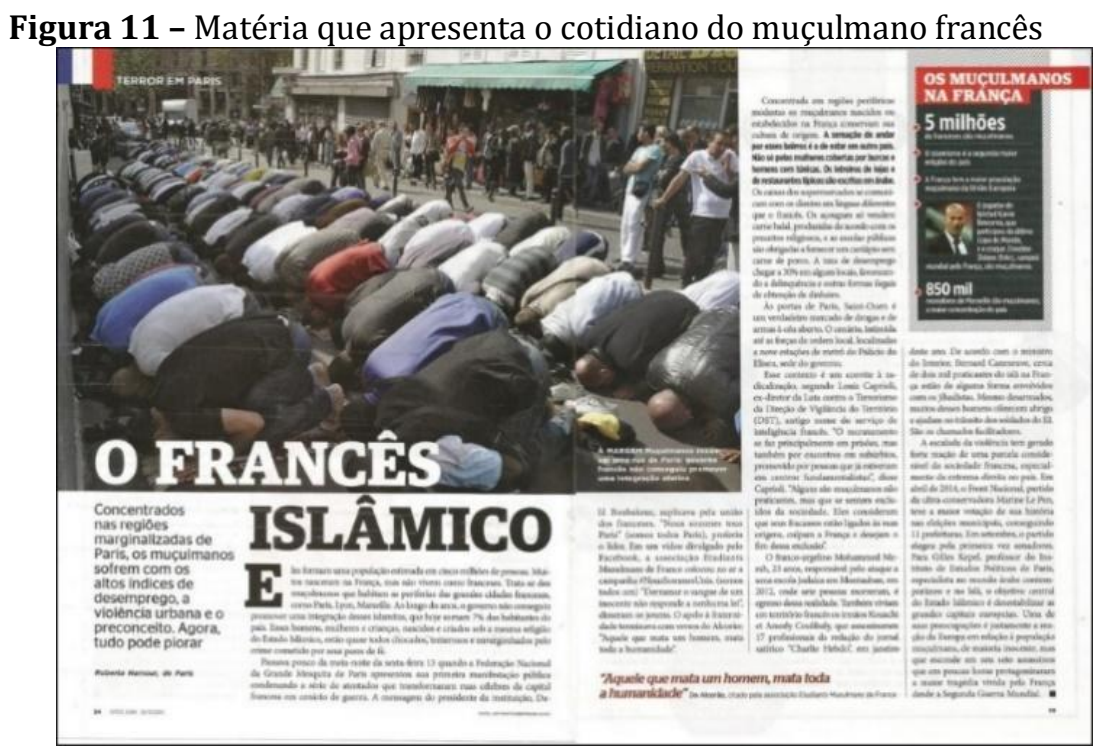

Fonte: Istoé (2015b, p. 54-55).

A imagem principal apresenta uma composição na qual a posição da câmera produziu diversas diagonais. Dentre elas, uma se destaca: aquela que separa a imagem entre dois grupos. 0 primeiro, formado pelas pessoas ajoelhadas; o segundo, pelas pessoas em pé.

${ }^{3}$ Recomenda-se a leitura do artigo Europe's Muslim future (KAUFMANN, 2010). 
Se, por um lado, a imagem apresenta uma divisão por meio da diagonal e a diferente postura dos retratados, por outro, o fato de não haver espanto por parte daqueles que não praticam a prece reforça a ideia de certa integração.

Figura 12 - Detalhe da fotografia da matéria sobre o cotidiano do muçulmano francês.

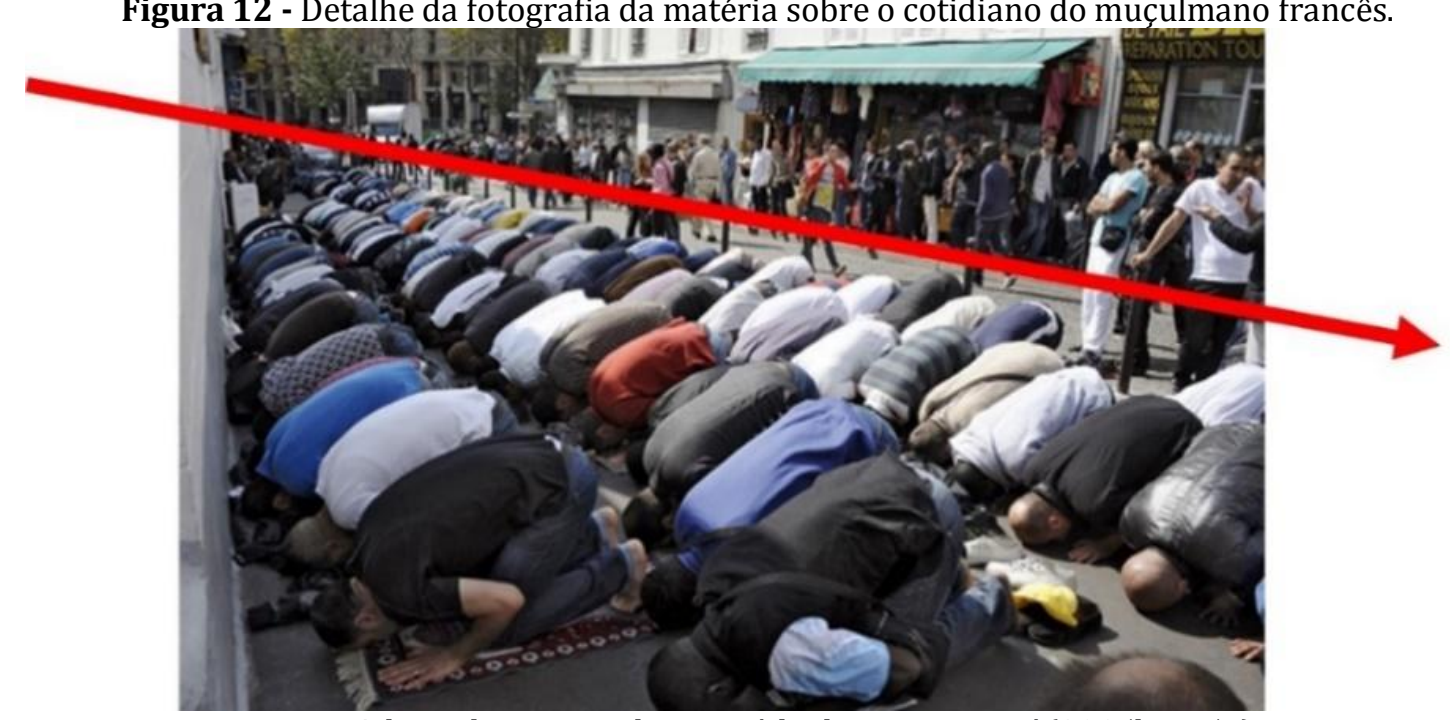

Fonte: Adaptado a partir de conteúdo da revista Istoé (2015b, p. 54).

Pela expressão daqueles que dividem o espaço da rua, podemos perceber que eles não parecem se importar com o que está acontecendo do outro lado da via, como se a prática, da qual não participam, fosse algo com o qual já estariam acostumados.

Os mulçumanos estão "integrados" e sem precisar abrir mão dos seus costumes em público. Há uma aparente harmonia, pelo menos, na foto. Apesar de terem costumes diferentes, não são apresentados como uma ameaça ao "modo de vida francês". Sua potência de ameaça encontra-se diminuída e a revista faz a distinção entre muçulmanos e terroristas.

Em função da temática da reportagem ser justamente os ataques, o número de mulçumanos não terroristas retratados, visualmente, é reduzido, mas, mesmo assim, encontra-se, também, a figura do "muçulmano bem-sucedido". Na reportagem que tem 28 páginas, o único apresentado imageticamente, como exemplo de "homem de sucesso", é o jogador/treinador Zinezine Zidane (Fig. 13), capitão da seleção francesa campeã do mundo de 1996, ídolo do esporte na França e no mundo. 
Figura 13 - Destaque do box sobre os muçulmanos esportistas "bem-sucedidos"

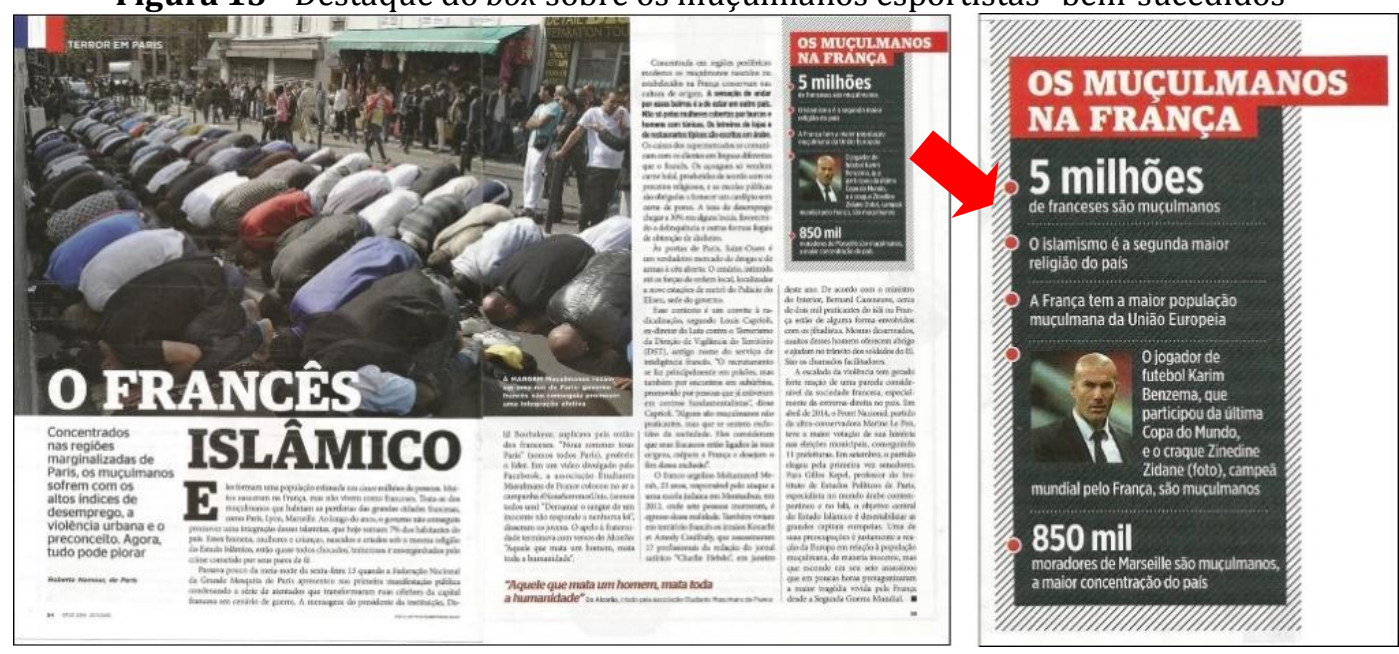

Fonte: Adaptado a partir de conteúdo da revista Istoé (2015b, p. 54-55).

Ao lado da foto do esportista, lê-se o nome completo do craque, deixando mais evidente sua ascendência árabe. 0 mesmo pode-se dizer de outro atleta famoso da seleção de futebol: Karin Benzema, citado no texto do box, seria, também, um muçulmano bem integrado ao mundo ocidental. ${ }^{4}$

A imagem utilizada para representar Zidane mostra-o barbeado, com terno e gravata, sugerindo-o em posição de comando. A fotografia está dentro de um box cujo texto mostra ao leitor, por meio de dados, como a França tinha, naquele momento, uma forte presença muçulmana. A figura ajuda a construir uma imagem mais positiva dos muçulmanos, reforçando para o leitor que, entre os seguidores do Islã que vivem na França, muitos não são uma ameaça ao estilo de vida do país.

Por fim, na última matéria da edição (Fig. 14), a imagem do muçulmano mascarado vai reaparecer multiplicada em um campo de treinamento no deserto, de maneira a sugerir que eles constituem um grupo organizado, disciplinado, armado e perigoso. Ao explicar para o leitor a origem e a engrenagem de funcionamento do EI ("Como nasce o terror"), ancora-se a estranheza a uma cadeia narrativa que tenta minimizar a não familiaridade do fato noticiado.

\footnotetext{
${ }^{4}$ Cabem dois comentários a respeito desses exemplos: o primeiro é que Zidane, apesar de ser um dos maiores jogadores dos "Bleus", foi expulso na final da Copa do Mundo de 2006 por agredir violentamente um jogador italiano, fato marcante em sua carreira. Já Benzema, do Real Madrid, é um jogador polêmico, que já foi acusado de desrespeitar o hino francês e, em 2016, de estar envolvido em um escândalo por supostamente tentar chantagear um colega de seleção (GLOBO ESPORTE, 2015).
} 
Figura 14 - Página interna da edição especial sobre o segundo atentado.

\section{COMO NASCE O TERROR}

Os extremistas do Estado Islâmico ascenderam depois da desastrada operação dos EUA no Iraque. Agora, propagam o fim dos tempos e defendem a morte para todos que não os seguirem

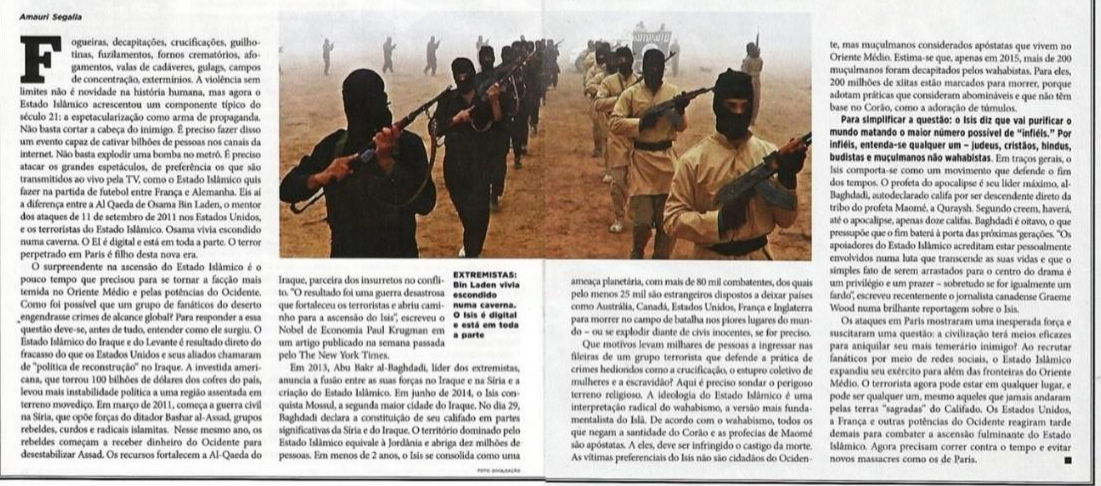

Fonte: Istoé (2015b, p. 56-57).

Uma das matrizes de sentido que, possivelmente, pode ser acionada por essa fotografia é a da imagem de "guerreiro", assim como de "inimigo". Enquanto o subtítulo veicula a ideia de que a incompetência dos Estados Unidos, nas suas recentes intervenções no mundo árabe, seria a responsável pelo surgimento de tais ameaças, na legenda da fotografia, a palavra "extremistas" confirma a informação de que os homens representados na imagem são guerreiros radicais armados e, portanto, perigosos.

O conteúdo do texto da legenda expressa uma diferença entre o terror praticado por Bin Laden e aquele exercido pelo EI, caracterizando o segundo como mais efetivo que o primeiro. Os terroristas são associados, na primeira reportagem em janeiro, à Al-Qaeda. Já nesta segunda narrativa, o sentido de ameaça e perigo ultrapassa a rede de Osama Bin Laden e apresenta ao leitor um inimigo ainda mais cruel. Assim, o processo de ancoragem aciona, também, uma bagagem baseada na memória coletiva para construir um novo sentido a respeito do terror e do próprio Estado Islâmico.

Ao explicar que o EI estaria em um nível de periculosidade acima da rede de Bin Laden, tendo capacidade comunicativa mais tecnológica, uma possível gama de sentidos que poderia ser acionada é: se a Al-Qaeda, cujo líder estava escondido em uma caverna, foi capaz de cometer atos tão terríveis, o que poderá realizar o hiperconectado EI? Afinal de contas, eles "estão em toda a parte" - podem ser um vizinho, principalmente no caso dos europeus. Como guia de orientação, o processo de representação também prescreve, aqui neste caso, uma conduta de cuidado e de combate imediato ao inimigo. 
Até aqui percebemos diversos exemplos do processo de ancoragem na narrativa da Istoé sobre os dois atentados ocorridos em 2015 na França. Contudo, onde estaria presente o outro braço da Teoria da Representação Social, de Serge Moscovici: a objetivação? Antes de explorarmos tal elemento, é preciso relembrar o que seria esse mecanismo na perspectiva do autor.

Conforme já comentamos, uma vez sanada ou minimizada a não familiaridade de um fato pelo processo de ancoragem, o ciclo da representação social completa-se quando o elemento novo se objetiva, se apresenta como dado na realidade social. De acordo com Moscovici (2007), o que era ruptura torna-se familiar e, finalmente, converte-se em algo do âmbito da obviedade. A objetivação diz respeito justamente ao deslocamento de um elemento do campo abstrato para a esfera concreta.

Portanto, em um primeiro momento, os fatos apresentam-se pela via do sensível e do cognoscível, nos levando a decifrar fenômenos outrora estranhos. Em um segundo instante, o elemento é incorporado à tessitura social, naturalizado e embutido de um significado que passa a ser seu correspondente único e dado: “[...] as imagens tornam-se elementos da realidade, em vez de elementos do pensamento." (MOSCOVICI, 2007, p. 74).

Moscovici (2007) explica que buscamos equivalentes não verbais para as palavras, para uma semântica coletiva formada em conjunto. Tal equivalente pode ser uma imagem ou um complexo de imagens. Em um movimento de adaptação, de ingresso sutil na gramática social, a representação torna-se a própria realidade: significa o que sempre teria que significar. As palavras, ou as nomeações e categorizações passam a existir objetivamente, independentes, com sentidos imediatos e próprios. Nesse processo, acabamos esquecendo que o significado foi uma construção realizada por nós mesmos, por meio da interação e da linguagem que compartilhamos. "Os nomes, pois, que inventamos e criamos para dar forma abstrata a substâncias ou fenômenos complexos, tornam-se a substância ou o fenômeno." (MOSCOVICI, 2007, p. 77, grifo do autor).

Nesse sentido, percebemos um eco com o pensamento de Michel Foucault (2001, 2009), quando o filósofo francês menciona a "vontade de verdade" dos discursos: um sistema de exclusão que permite às formações discursivas serem aceitas na tessitura social, como se nenhuma outra pudesse ser possível de existir, ocultando o processo que permitiu ou não o ingresso de enunciados na ordem do discurso.

Assim, o muçulmano vítima aparece para não nos esquecermos da existência dada do seu oposto imediato: o islamita algoz. 0 muçulmano bem-sucedido surge como um elemento 
que precisa ser destacado, pois é um fator não rotineiro no imaginário do mundo europeu. E, por fim, o processo de objetivação do muçulmano terrorista alcança o ápice de concretude na imagem do mal a ser combatido, do inimigo, do fator estrangeiro que precisa ser eliminado. Aliar a conceituação do Estado Islâmico à Al-Qaeda (e depois ainda afirmar de que o EI é uma rede ainda mais perigosa), também, faz parte do mecanismo de objetivação desse "novo" ator social. Entender o muçulmano terrorista do EI é tentar fazer as "[...] coisas conhecidas a partir do que já é conhecido [...]" (MOSCOVICI, 2007, p. 77).

Dialeticamente, é possível perceber que a entrada do Estado Islâmico na cena pública internacional contribuiu para consolidar, também, a objetivação da noção de terrorismo contemporâneo. Para deslocarmos o componente simbólico (o terror) para um âmbito mais palpável, novas faces, práticas, rotinas e sujeitos são apresentados. 0 terror dos dias atuais, que já havia alcançado para o Ocidente, certo grau de concretude com a AlQaeda, intensifica sua existência própria com o EI. A coerência da narrativa linear da Istoé deixa tal ponto bem claro. Do choque inicial com o ataque ao Charlie Ebdo, seguindo pela tentativa de interpretar quem eram os autores dos atentados em série ocorridos dez meses depois, a narrativa culminou na definição do elemento indesejado: o terrorismo, na sua nova roupagem, carrega o sobrenome de Estado Islâmico.

Apesar de tocar na questão da origem e das motivações do EI, uma das mensagens finais que pode ser extraída das duas edições é de que o terror assumiu o status de uma entidade a serviço do caos (concreto). 0 terror precisa, agora, ser aceito como uma realidade, um fato social (se pensarmos no termo durkheimniano) que se apresenta perante cada um de nós.

\section{Considerações finais}

Ao fim das análises, foi possível compreender que, ao longo do processo de representação social dos atentados terroristas ocorridos em 2015, a revista Istoé cumpriu um trajeto narrativo/explicativo que se estendeu pelas duas edições analisadas. Em relação aos eventos ocorridos na França em novembro, aquilo que se encontrava na dimensão do "incompreensível" foi explicado, interpretado, categorizado e, finalmente, integrado a certa semântica social, a fim de que o leitor brasileiro pudesse entender esses dois fatos considerados relevantes para o mundo ocidental. 
Evidentemente, a publicação não realizou tal tarefa sozinha. Atravessada por muitas vozes, a narrativa da Istoé contou com a ajuda de autoridades, especialistas, recursos imagéticos e icônicos, além de material de acervo, a fim de elaborar as representações veiculadas em suas páginas. Externamente à revista, podemos destacar o noticiário da televisão e das redes sociais como integrantes cruciais dessa polifonia.

A análise que propusemos fazer aqui independe das intenções dos repórteres, editores e diagramadores - até porque, para alcançá-las, outra metodologia se faria necessária. No entanto, longe de sugerir uma leitura preferencial (HALL, 2003), ou até mesmo única, buscamos entender uma das possíveis redes de sentido formadas pela revista em relação à figura do muçulmano.

A utilização da abordagem de Moscovici (1978, 2007, 2012) se fez importante, principalmente, pelo fato de sua perspectiva lançar luz ao fato de como os meios de comunicação comportam-se quando surge algo novo em uma sociedade, uma ruptura com aquilo que é cotidiano, surgindo tensões ou desequilíbrios, que buscam ser traduzidos e entendidos pela via da linguagem. Nesse texto destacamos dois instantes acontecimentais em que a revista procurou explicar os atos terroristas, as motivações e as consequências desses atos e, nesse processo, também, acabou por caracterizar o seguidor do Islã.

Essa perspectiva também nos ajudou a compreender melhor como os meios de comunicação contribuem para a estruturação da nossa perspectiva cognitiva sobre o mundo e, a partir dessa percepção, notamos a necessidade de nos atentarmos para a capacidade expressiva e retórica da combinação entre texto e imagem. No que se refere às fotografias utilizadas, é importante destacar que não é apenas o conteúdo que importa, mas também o aspecto compositivo. 0 "como" uma imagem é criada e apresentada não apenas organiza a imagem, mas também atua no sentido de organizar nossa percepção. Nesse sentido, vale destacar que a única figura da mulher muçulmana veiculada na reportagem (Fig. 8), apresenta-a caracterizada como mulher-mãe, vítima da polícia ocidental. Essa escolha ajuda a naturalizar não apenas a relação do oriental/muçulmano como o bárbaro a ser temido e pacificado, mas também a posição inferior dessa mulher na cultura do Islã.

Conforme já foi visto ao longo das análises, percebemos que existem algumas tipologias (categorias) que se repetem em ambas as edições, seja em relação ao muçulmano terrorista, ao mulçumano bem-sucedido ou ao muçulmano vítima. 0 primeiro, na maioria das vezes, é representado visualmente por uma figura vestida de preto, com o rosto escondido (até que seja identificado), caracterizado verbal e visualmente como autor de ações 
bárbaras. No entanto, ele também é apresentado como um sujeito nascido e criado na Europa, participante da vida da população local. É então uma pessoa de difícil detecção identitária, dotado de uma grande periculosidade e que pode estar em qualquer lugar.

Se, em uma primeira análise, mais superficial, poderíamos verificar que a revista acionou os preconceitos tradicionais sobre os mulçumanos (no caso da categoria mulçumano terrorista), ao nos debruçarmos sobre o texto e as imagens veiculados na Istoé, percebemos que, apesar da presença de alguns estereótipos, eles não se constituíram como as únicas representações acionadas pela revista. Um bom exemplo disso é a visibilidade que a Istoé deu para os mulçumanos bem-sucedidos, que pode ser comprovada na figura do líder árabe (Fig. 4) e do jogador de futebol/técnico famoso (Fig. 13). Além disso, há a caracterização do islamita "comum" que reside na Europa como vítima, um dos muitos atores sociais que devem ser protegidos da grande ameaça que representam os terroristas.

0 veículo não fugiu à tarefa de procurar apresentar, mesmo que minimamente, um panorama mais complexo da situação na França - em vez de se concentrar em fixar a figura muçulmana apenas ao mal e à periculosidade. Ao contrário de narrativas que tendem a fazer um apelo mais contundente e reducionista, a reportagem da revista Istoé trouxe para o leitor brasileiro uma abordagem com razoável aprofundamento do assunto, contribuindo para uma definição um pouco mais rica do que é o muçulmano e, assim, adotando uma postura que se espera da imprensa: menos respostas pré-determinadas e mais convites à reflexão.

Voltando à ideia de que os meios de comunicação contribuem para a estruturação da nossa perspectiva cognitiva sobre o mundo, entendemos que essa postura da revista Istoé é fundamental para escapar ao reducionismo, mas não é suficiente. Uma estratégia que contribuiria para evitar essa polarização, na qual o muçulmano é visto como um ser terrorista bárbaro, é a produção de matérias que deem destaque a islamitas, homens e mulheres, que atuam na comunidade ocidental, especialmente na brasileira.

Aqui vale destacar que, se, por um lado, desde o ano de 2015, não houve uma produção relevante/suficiente de reportagens com essas características, por outro, houve modificação na cobertura dos atentados terroristas. Tal fato ocorre após uma discussão na sociedade em que a cobertura da mídia foi questionada ao contribuir para a divulgação da imagem do EI. Assim, novas estratégias foram criadas para abordar esse tema. 
Um exemplo dessa mudança pode ser percebido na retrospectiva da própria Istoé de 2017, na qual, para falar da nova estratégia terrorista de usar carros para cometer ataques, não foi usada uma imagem que vinculasse muçulmanos ao terror, assim como, os vocábulos mulçumano, islã ou islamita não apareceram (ISTOÉ, 2017, p. 89).

Por fim, é preciso lembrar que as representações são convenções e foram acionadas pela Istoé em sua narrativa, mas nem por isso deixam de ser variáveis. 0 consenso é definido entre disputas por diferentes atores sociais. As representações são apropriadas pelos indivíduos - e pelos veículos - em inúmeras situações e configuram-se como ingrediente constitutivo das nossas interações comunicativas, originando interpretações que são elaboradas e ressignificadas pela própria dinâmica da sociedade. Em outras ocasiões, em outros meios de comunicação ou em outros períodos, tais mecanismos representacionais podem fornecer análises bem distintas da que foi aqui realizada. Do mesmo modo, o acionamento de outros aportes conceituais poderia resultar em conclusões de diferente natureza.

\section{Referências}

AGÊNCIA BRASIL. Primeiro-ministro do Japão diz que Tóquio "não se curva perante os terroristas". [S.l.]: EBC, 2015.

BARTHES, Roland. 0 óbvio e o obtuso: ensaios sobre fotografia, cinema, pintura, teatro e música. Rio de Janeiro: Nova Fronteira, 1990.

CENTRAL INTELLIGENCE AGENCY. The World Factbook. [S.I.]: CIA, [2017].

CHARTIER, Roger. À beira da falésia: a história entre incertezas e inquietude. Porto Alegre: UFRGS, 2002.

CHARTIER, Roger. A força das representações: história e ficção. Chapecó: Argos, 2011.

CHARTIER, Roger. História cultural entre práticas e representações. Rio de Janeiro: Bertrand Brasil, 1990.

CORRÊA, Laura Guimarães; SILVEIRA, Fabrício José N. da. Representação. In: FRANÇA, Vera; MARTINS, Bruno; MENDES, André Melo (Org.). Grupo de Pesquisa em Imagem e

Sociabilidade (GRIS): trajetórias, conceitos e pesquisa em comunicação. Belo Horizonte: PPGCOM-UFMG, 2014. p. 123-126.

DOISE, Willem; CLEMENCE, Alain; LORENZI-CIOLDI, Fabio. Représentations sociales et analyses de donnés. Grenoble: Presses Universitaires, 1992. 
DURKHEIM, Émile. Representações individuais e representações coletivas. In: DURKHEIM, Émile. Sociologia e filosofia. Rio de Janeiro: Forense Universitária, 1970. v. 2, p. 15-49.

FARR, Robert M. Representações sociais: a teoria e suas histórias. In: GUARESCHI, Pedrinho; JOVCHELOVITCH, Sandra (Org.). Textos em representações sociais. Petrópolis: Vozes, 1995. p. 31-59.

FOUCAULT, Michel. A arqueologia do saber. Rio de Janeiro: Forense Universitária, 2009.

FOUCAULT, Michel. A ordem do discurso: aula inaugural no College de France, pronunciada em 2 de dezembro de 1970. São Paulo: Loyola, 2001.

G1. Conheça o jihadista 'John', londrino comum que virou um carrasco cruel. [S.l.]: G1, 2015.

GLOBO ESPORTE. Benzema é afastado da seleção francesa por polêmica com Valbuena. [S.l.]: Globo, 2015.

GOFFMAN, Erving. A representação do eu na vida cotidiana. Petrópolis: Vozes, 2011.

HALL, Stuart. Da diáspora: identidades e mediações culturais. Belo Horizonte: UFMG, 2003.

HALL, Stuart. El trabajo de la representación. In: HALL, Stuart (Org.). Representation: cultural representations and signifying practice. London: Sage Publication, 1997.

HOURANI, Albert. Uma história dos povos árabes. São Paulo: Companhia das Letras, 2006.

ISTOÉ. São Paulo: Ed. Três, n. 2354, 14 jan. 2015a.

ISTOÉ. São Paulo: Ed. Três, n. 2399, 25 nov. 2015b.

ISTOÉ. São Paulo: Ed. Três, n. 2506, 21 dez. 2017.

JODELET, Denise. Les représentations sociales. Paris: Presses Universitaires de France, 2003.

JODELET, Denise. Loucuras e representações sociais. Petrópolis: Vozes, 2005.

JODELET, Denise. Représentation sociale: phénomènes, concept et théorie. In: MOSCOVICI, Serge (Ed.). Psychologie sociale. Paris: Presses Universitaires de France, 1984. v. 2, p. $357-$ 378.

KAUFMANN, Eric. Europe's Muslim future. Prospect, London, Apr. 2010.

LASMAR, Jorge M.; SINGH, Rashmi. Terrorismo contemporâneo. In: TEIXEIRA, Rodrigo Corrêa; RAMOS, Leonardo C. S. (Org.). Conflitos do século 21. Belo Horizonte: Fino Traço, 2017.

LEWIS, Bernard. 0 Oriente Médio: do advento do cristianismo aos dias de hoje. Rio de Janeiro: Zahar, 1996. 
MENDES, André Melo; DORNELAS, Raquel. Todos contra o terror: os atentados na França e a ação coletiva acionada por Istoé. Culturas midiáticas, João Pessoa, v. 10, n. 1, p. 115-134, jan./jun. 2017.

MOSCOVICI, Serge. A psicanálise, sua imagem e seu público. Petrópolis: Vozes: 2012.

MOSCOVICI, Serge. A representação social da psicanálise. Rio de Janeiro: Zahar, 1978.

MOSCOVICI, Serge. Representações sociais: investigações em psicologia social. Petrópolis: Vozes, 2007.

ORDAZ, Olga; VALA, Jorge. Objectivação e ancoragem das representações sociais do suicídio na imprensa escrita. Análise Social, Lisboa, v. 32, n. 143/144, p. 847-874, 1997.

SAID, Edward. Orientalismo: o oriente como invenção do ocidente. São Paulo: Companhia de Bolso, 2013.

SANTOS, Waldeir Eustáquio. Estado Islâmico no Oriente Médio: análises históricas, contemporâneas e o caso da Turquia. In: TEIXEIRA, Rodrigo Corrêa; RAMOS, Leonardo César Souza. Conflitos do século XXI. Belo Horizonte: Fino Traço, 2016. p. 187-230.

WEBER, Olivier. O feudo do terror. In: FOTORRINO, Eric (Org.). Quem é o Estado Islâmico? Compreendendo o novo terrorismo. Belo Horizonte: Autêntica, 2016.

WEISS, Michael; HASSAN, Hassan. Estado Islâmico: desvendando o exército do terror. São Paulo: Seoman, 2016.

\title{
Which muslim are we talking about? Anchorage and objectification in the representation of the islamist by Istoé magazine
}

\begin{abstract}
The paper aims to understand how the Muslim people were represented by the Istoe magazine after the terrorist attacks in France, in January and November of 2015. For this, we used the notions of anchorage and objectification, understanding them as central parts of Serge Moscovici's Social Representation Theory. When applying these concepts, we used as a theoretical tool image and textual analysis, thus comprehending how the representations presented in Brazilian magazines show other aspects of our own society and how these narratives problematize the practice of the press. We conclude that the two editions of the magazine represented three categories of Muslims: the successful, the victim and the terrorist - the last one embodied in the figure of the member of the Islamic State.
\end{abstract}




\section{Keywords}

Social Representation. Anchorage. Objectification. Muslim. Terrorism.

Recebido em 18/11/2017

Aceito em 19/02/2018 